\title{
KERABU BEKOR: EXPLORING THE TRADITIONAL FOOD KNOWLEDGE OF THE COMMUNITY IN THE LENGGONG SUB- DISTRICT OF HULU PERAK
}

\author{
Munira Saaidin \\ Faculty of Business \& Technology, UNITAR International University, Malaysia \\ Annis Jamaluddin \\ School of Culinary Arts, UNITAR International University, Malaysia \\ Erdaizzati Mohd Som \\ UNITAR College, UNITAR International University, Malaysia \\ Nur Juliana Azhari \\ School of Culinary Arts, UNITAR International University, Malaysia \\ W. Eddie Azlie W. Mohd Asri \\ School of Culinary Arts, UNITAR International University, Malaysia \\ Mislan Nenin \\ Faculty of Business \& Technology, UNITAR International University, Malaysia
}

\begin{abstract}
Traditional foods had been an important element of cultural heritage and they played an important role in establishing the local identity. The study focused in the area of the sub-district of Lenggong in the state of Perak. The purposes of this study on traditional foods, specifically one traditional food called Kerabu Bekor were to find out the main ingredients used in preparing and cooking the dish, and to determine the level of knowledge the community had on the dish. Five traditional food experts participated in providing vast descriptive information on Kerabu Bekor. The information were combined and the consensus were derived on each factors examined. Audio-visual aids were used to help in understanding further on how the dish is prepared by the experts. Forty-six members of the community were involved in providing feedback on the level of knowledge that they had on the ingredients, the methods of preparation, cooking, serving and consumption of Kerabu Bekor. On examining the results, both the male and female respondents indicated that they have
\end{abstract}


Kerabu Bekor: Exploring the Traditional Food Knowledge of the Community in the Lenggong SubDistrict of Hulu Perak

some knowledge, but on the age categories, 2 age groups (25 to 29 years and 30 to 39 year old) had a full understanding on the details of Kerabu Bekor, while the other 3 groups only had partial knowledge.

Key words: Kerabu Bekor, Traditional food knowledge, Local cuisine.

Cite this Article: Munira Saaidin, Annis Jamaluddin, Erdaizzati Mohd Som, Nur Juliana Azhari, W. Eddie Azlie W. Mohd Asri and Mislan Nenin, Kerabu Bekor: Exploring the Traditional Food Knowledge of the Community in the Lenggong SubDistrict of Hulu Perak, International Journal of Management, 11(12), 2020, pp 625-637.

http://iaeme.com/Home/issue/IJM?Volume=11\&Issue=12

\section{INTRODUCTION}

Traditional Food Knowledge (TFK) referred to as a cultural tradition of sharing food, recipes and cooking skills and techniques, and passing down that collective wisdom through generations (Kwik (2008). He further stated that the traditional food knowledge could be one means of asserting cultural identity and could be a way to connect people to the natural world. Some ethnic groups were reported not only facing the deskilling issues related to domestic cooking skills, but had begun to lose the traditional food culture due to the inability of the elder generations to pass down the traditional cooking knowledge to the younger generations (Stringer, 2009; Bowen and Devine, 2011).

Kwik (2008) stated that the distinct expressions of taste and place were facing a continuity gap when traditional food knowledge had not been passed forward, but rather sidelined as abstract, historical concept. Preserving Traditional Food Knowledge (TFK) had received greater concern among the older generations as indicated by the Malaysian Cultural Association of the Ministry of Information, Communication and Culture, and other government agencies.

The research issues addressed the need to understand the concept of traditional food knowledge and to suggest innovative approaches to help communities to appreciate and to retain the traditional food knowledge as a form of cultural heritage. This study addressed the need for the development of knowledge on traditional foods, their origins, the special ingredients, and the specialized methods of preparation. The findings from this study could contribute towards the preservation of traditional foods in the study area.

Based on the research issues, the following questions would be addressed:

- Are there identifiable traditional foods in the study area?

- What are the main ingredients, the preparation and cooking methods?

- Are there special or specific occasion when the food is prepared and consumed (foodways) of those traditional foods?

- What are the awareness and the level of knowledge among the community members on the traditional foods?

Thus the purpose of the research was to (1) Identify the traditional foods in area of study, (2) find out the ingredients and the common methods of preparation and cooking of the identified traditional foods and (3) determining the level of foodways knowledge on the identified traditional foods amongst the community members. 
Definitions of Concepts and terms

\section{Traditional Foods}

Foods that have been consumed for many generations which includes all indigenous food plants found in that region or locality (European Union, 2007). In other words, traditional foods are those foods originating locally in an area with respect to the country, region, district or sub district (Ohiokpehai, 2003).

\section{Traditional Food Knowledge (TFK)}

The cumulative teachings and experience gained from the process of sharing foodways from generation to generation. Traditional food knowledge is a concept which encompasses indigenous and immigrant populations and focuses on the process of learning and sharing (Kwik, 2008).

\section{Foodways}

Principally, foodways is a combination of two words which are 'food' and 'ways' and refers to the way food is prepared, served, and consumed by human beings. Simply understood as the preparation and consumption of food (Noriza, Mohd Zahari, Shazali \& Rosmaliza, 2012).

\section{LITERATURE OVERVIEW}

The Centre of Excellence in Nutrition and Metabolism (CENM) indicated that the preparation methods of traditional foods were often part of folklore of a country or a region. The Centre further identified traditional food as food with a specific feature or features which distinguish it clearly from other similar products of the same category in terms of the use of "traditional ingredients" (raw material of primary products) or "traditional composition" or "traditional type of production and/or processing method. Lestari (2014) further added that traditional foods are foods and beverages that are commonly consumed by a particular community and the distinctive flavor had been widely accepted by the community. Ohiokpehai, (2003) also indicated that traditional foods are those foods originating locally in an area with respect to the country, region, district or sub district.

(Kwik, 2008) stated that the concept of traditional food knowledge had been integrated across several academic disciplines such as social, cultural, and nutritional anthropology, human ecology, agriculture, population health, family studies, community development, and education, among others. Thus, the study on traditional food knowledge could be approached from various perspectives. One of the focus would be to understand the many implications of the tradition foods for the ecosystem health of a community. Kwik added that when blending those different perspectives, it would provide the opportunity to find innovative approaches to ensure that the knowledge on the traditional food would be preserve. Jordana (2000) who had extensively studied traditional foods indicated that those foods should include foods that have been consumed locally or regionally for an extensive time period and that the preparation and cooking methods of such foods have been passed down through generations and are now part of the folklore of the people. Kristbergsson (2016) also noted that the knowledge on those foods had been passed through generations and had been consumed by many generations.

Traditional food knowledge could provide an individual with the capacity to prepare meals that are nutritious, safe, and culturally relevant (Kwik, 2008). He added that the skills could support the adaptation to altered food environments, for example for immigrants and indigenous people. These would be specific and personal and the community would benefit by gaining or learning traditional food knowledge. Thus, the community knowledge would increase with a greater number of skilled practitioners and educated consumers. Information 
sharing of the cultural life skills where people from various walks of life could share and learn and could promote better understand among the community members. As elaborated by Jaffe and Gertler, (2006), for the immigrant cultures, the maintenance of traditional food knowledge would be even more important because it could provide a foundation for selfidentification that would bridge the cultural gap between generations that associate them with the common geographical link of their past with their present.

Traditional foods had been an important element of cultural heritage and they played an important role in establishing the local identity and consumer behavior. Additionally, the traditional foods had been very important for rural development and for the sustainability of small and medium size country (Jordana, 2000). Traditional Food Knowledge (TFK), Heritage Foods and the preparation and consumption of those foods had been the focus of studies on the Malaysian Traditional Foods (Hamzah, Ab Karim, Othman and Hamzah, 2013; Muhammad, Mohd Zahari, Mohamad Abdullah and Md. Sharif, 2014; Suhaimi and Mohd Zahari, 2014; Md. Sharif, Mohd Zahari, Ishak, Muhammad, Md Noor and Mohd Salleh, 2012; Langgat, 2011; Jalis, 2009; Tibere and Aloysius, 2013). Synchronizing all the issues that had been highlighted, the important task would be to create a significant amount of curiosity and awareness on the traditional food knowledge amongst the youths/community members on the traditional foods. Chenhall (2011) noted that the transition of traditional food practices had been decreasing among the young generations primarily owing to the increased availability of processed, pre-prepared and convenient foods within the retail and foodservice environments. A study by Wahyudi David, (2014) from the Universitas Bakrie which explored the potential of traditional foods as a means of fostering the nutrition awareness and the perception of young people towards their traditional foods, found that the young people would only be concerned on the nutritional value of food when there were evidence that there were foodrelated health issues associated with their demographic group.

\section{RESEARCH METHODOLOGY}

The enquiry of the study is guided by the case research design where the qualitative and quantitative data and information is combined to provide explanation of the phenomena under investigation. The qualitative approach had been applied in the process of identify and securing information on the tradition foods available in the study area. It would allow for the detail explanation on the preparation, cooking and consumption of the tradition foods and other related information. The quantitative approach had also being used to help understand the level of awareness and knowledge on the foodways of the youths/community members

The site selected for the study was the sub-district of Lenggong in the district of Hulu Perak, in the state of Perak, Malaysia. This sub-district is quite secluded from the urban development areas and thus, had not been affected by the amalgamation or fusion of the different ethnic foods in the populated areas. The area covers about 6,560 sq. kilometers and is surrounded on almost all sides by primary and secondary forests. The East-West Highway run alongside the area. The residents in the area is mostly Malays with the Orang Asli settling at the fringes of the forests. Other minor ethnic group comprised of the Malaysian Chinese (about 10\%) and Malaysian Indians (about 2\%). The immigrant community accounted for less than $2 \%$.

There are two groups of respondents identified to be included in this study: (1) Group 1 which consisted of five (5) Traditional Food Experts. The list of names of the food experts were supplied by the head of communities and through the shortlisting process, the 5 names were selected. The shortlisting process involved their agreement to cooperate and to supply the needed information. (2) Group 2 consisted of forty-six (46) respondents - the 
youths/community members who were given the questionnaires. The selection was mainly based on their initial knowledge on the traditional food to be investigated.

Two types of data were collected: (1) primary data collected via face-to-face discussions, interviews and also information derived from the audio-visual recording with the 5 traditional food experts; and the information derived from the responses from the questionnaires respondents. (2) secondary data were collected from journal articles, published information from the Hulu Perak district office, the Lenggong office of the district councils, and information from the Perak Tourism Office.

There were 2 types of instruments required to acquire information on the (1) Structured Questionnaires which were aimed at aimed at finding out the demographic profiles of the respondents, their overall level of knowledge on traditional foods, and their level of knowledge on the Traditional Food. The 5-point Likert-like scale was used to group the information.

Table 1

\begin{tabular}{|c|c|c|c|c|}
\hline $\begin{array}{c}\text { Strongly } \\
\text { Disagree }\end{array}$ & Disagree & $\begin{array}{c}\text { Slightly } \\
\text { Disagree }\end{array}$ & Agree & $\begin{array}{c}\text { Strongly } \\
\text { Agree }\end{array}$ \\
\hline 1 & 2 & 3 & 4 & 5 \\
\hline
\end{tabular}

The following scale was used to determine the summary of findings on the overall level of knowledge and the specific knowledge on the 3 traditional foods:

Table 2

\begin{tabular}{|c|c|c|c|c|}
\hline Strongly Disagree & Disagree & Slightly Disagree & Agree & Strongly Agree \\
\hline $\begin{array}{c}\text { No } \\
\text { Knowledge }\end{array}$ & $\begin{array}{l}\text { Hardly Any } \\
\text { Knowledge }\end{array}$ & $\begin{array}{c}\text { Slight } \\
\text { Knowledge }\end{array}$ & $\begin{array}{c}\text { Partial (Some) } \\
\text { Knowledge }\end{array}$ & $\begin{array}{c}\text { Full } \\
\text { Knowledge }\end{array}$ \\
\hline $1.00-1.99$ & $2.00-2.99$ & $3.00-3.99$ & $4.00-4.99$ & 5.00 \\
\hline
\end{tabular}

(2) Qualitative Instrument: Open-ended Questionnaires which is aimed at tapping the traditional foods experts' knowledge on the Traditional Food. The following 8 open-ended factors were directed at the 5 traditional foods experts. The purpose of each question was to derive a consensus on the responses to the following 8 factors.

\begin{tabular}{|l|l|}
\hline Factor 1 & Main ingredients to prepare the traditional food \\
\hline Factor 2 & Preparation of the traditional food \\
\hline Factor 3 & Equipment used to prepare the traditional food \\
\hline Factor 4 & Where the traditional food originate from \\
\hline Factor 5 & Occasion the traditional food will be served \\
\hline Factor 6 & For whom the traditional food is served \\
\hline Factor 7 & The manner the food is served \\
\hline Factor 8 & Accompanying Food that is served with the traditional food \\
\hline
\end{tabular}


Kerabu Bekor: Exploring the Traditional Food Knowledge of the Community in the Lenggong SubDistrict of Hulu Perak

\section{RESEARCH FINDINGS}

\subsection{Level of General Knowledge on Kerabu Bekor}

\subsubsection{Partitioning of Gender with Level of Knowledge on Kebebe as the Traditional Food of Hulu Perak}

On partitioning of gender with level of knowledge on Kerabu Bekor as the traditional food of Hulu Perak, the detailed findings were as indicated in Table 3. The findings indicated that all the male and female respondents stated that they had some knowledge (1) in the preparation of Kerabu Bekor, that the bekor fruit needed to be grilled and the skin peeled, (2) that the bekor fruit needed to be thinly cut in long strands, (3) that the major ingredients used in making Kerabu Bekor were fried coconut paste (Kerisik), shrimp paste, bird's eye chilies, lemon grass, galangal, kesom leave, and salt, (4) that caution had to be made on the choice of coconut milk to be used in preparing Kerabu Bekor, and that (5) Kerabu Bekor could be served as daily food, for events such as feast and breaking fast.

Table 3 Partitioning of Gender with Level of Knowledge on KERABU BEKOR as the Traditional Food

\begin{tabular}{|c|c|c|c|}
\hline \multirow[b]{2}{*}{ NO. } & \multirow[b]{2}{*}{ STATEMENT } & \multicolumn{2}{|c|}{ AVERAGE SCORE } \\
\hline & & $\begin{array}{c}\text { Male } \\
(19 \text { Resp) }\end{array}$ & $\begin{array}{l}\text { Female } \\
\text { (27 Resp) }\end{array}$ \\
\hline 1 & $\begin{array}{l}\text { In the preparation of Kerabu Bekor, the beko fruit need } \\
\text { to be grilled and the skin peeled }\end{array}$ & $\begin{array}{l}\text { Some } \\
\text { K'ledge } \\
4.47\end{array}$ & $\begin{array}{c}\text { Some } \\
\text { K'ledge } \\
4.74\end{array}$ \\
\hline 2 & The beko fruit needed to be thinly cut in long strands & $\begin{array}{c}\text { Some } \\
\text { K'ledge } \\
4.58\end{array}$ & $\begin{array}{c}\text { Some } \\
\text { K'ledge } \\
4.59\end{array}$ \\
\hline 3 & $\begin{array}{l}\text { The major ingredients used in making Kerabu Bekor } \\
\text { are fried coconut paste (Kerisik), shrimp paste, bird's } \\
\text { eye chilies, lemon grass, galangal, kesom leave, and } \\
\text { salt. }\end{array}$ & $\begin{array}{c}\text { Some } \\
\text { K'ledge } \\
4.47\end{array}$ & $\begin{array}{c}\text { Some } \\
\text { K'ledge } \\
4.81\end{array}$ \\
\hline 4 & $\begin{array}{l}\text { Caution on the choice of coconut milk to be used in } \\
\text { preparing Kerabu bekor }\end{array}$ & $\begin{array}{c}\text { Some } \\
\text { K'ledge } \\
4.63\end{array}$ & $\begin{array}{c}\text { Some } \\
\text { K'ledge } \\
4.46\end{array}$ \\
\hline 5 & $\begin{array}{l}\text { Kerabu Bekor can be served as daily food, for events } \\
\text { such as feast and breaking fast. }\end{array}$ & $\begin{array}{c}\text { Some } \\
\text { K'ledge } \\
4.21\end{array}$ & $\begin{array}{c}\text { Some } \\
\text { K'ledge } \\
4.56\end{array}$ \\
\hline
\end{tabular}

\subsubsection{Partitioning of Age Category with Level of Knowledge on KERABU BEKOR as the Traditional Food of Hulu Perak}

Table 4 indicated the partitioning of respondents by age category with level of knowledge on Kerabu Bekor as the traditional food of Hulu Perak. Those in the age categories of 25 to 29 and 30 to 39 years old stated that they had full knowledge on all the 5 aspects of Kerabu Bekor in that (1) the preparation of Kerabu Bekor, the bekor fruit needed to be grilled and the skin peeled, (2) that the beko fruit needed to be thinly cut in long strands, (3) that the major ingredients used in making Kerabu Bekor were fried coconut paste (Kerisik), shrimp paste, bird's eye chilies, lemon grass, galangal, kesom leave, and salt, (4) that caution had to be made on the choice of coconut milk to be used in preparing Kerabu bekor, and that (5) Kerabu Bekor could be served as daily food, for events such as feast and breaking fast.

The other 3 categories of age groups were in reference to those in the 18 to 24,40 to 49 and those with 50 and above age groups that they only had some or partial knowledge on those five aspects of Kerabu Bekor. 
Munira Saaidin, Annis Jamaluddin, Erdaizzati Mohd Som, Nur Juliana Azhari,

W. Eddie Azlie W. Mohd Asri and Mislan Nenin

Table 4 Partitioning of Age Category with Level of Knowledge on KERABU BEKOR as the Traditional Food

\begin{tabular}{|c|c|c|c|c|c|c|}
\hline \multirow[b]{2}{*}{ NO. } & \multirow[b]{2}{*}{ STATEMENT } & \multicolumn{5}{|c|}{ AVERAGE SCORES } \\
\hline & & $\begin{array}{c}\text { 18-24 } \\
\text { (3 Resp) }\end{array}$ & $\begin{array}{c}25-29 \\
\text { (3 Resp) }\end{array}$ & $\begin{array}{l}\text { 30-39 } \\
(2 \text { Resp) }\end{array}$ & $\begin{array}{c}40-49 \\
(17 \\
\text { Resp) }\end{array}$ & $\begin{array}{c}50+ \\
(21 \text { Resp) }\end{array}$ \\
\hline 1 & $\begin{array}{l}\text { In the preparation of Kerabu Bekor, the } \\
\text { beko fruit need to be grilled and the skin } \\
\text { peeled }\end{array}$ & $\begin{array}{c}\text { Some } \\
\text { K'ledge } \\
4.75\end{array}$ & $\begin{array}{c}\text { Full } \\
\text { K'ledge } \\
5.00\end{array}$ & $\begin{array}{c}\text { Full } \\
\text { K'ledge } \\
5.00\end{array}$ & $\begin{array}{l}\text { Some } \\
\text { K'ledge } \\
4.79\end{array}$ & $\begin{array}{c}\text { Some } \\
\text { K'ledge } \\
4.43\end{array}$ \\
\hline 2 & $\begin{array}{l}\text { The beko fruit needed to be thinly cut in } \\
\text { long strands }\end{array}$ & $\begin{array}{c}\text { Some } \\
\text { K'ledge } \\
4.25\end{array}$ & $\begin{array}{c}\text { Full } \\
\text { K'ledge } \\
5.00\end{array}$ & $\begin{array}{c}\text { Full } \\
\text { K'ledge } \\
5.00\end{array}$ & $\begin{array}{c}\text { Some } \\
\text { K'ledge } \\
4.72\end{array}$ & $\begin{array}{c}\text { Some } \\
\text { K'ledge } \\
4.46\end{array}$ \\
\hline 3 & $\begin{array}{l}\text { The major ingredients used in making } \\
\text { Kerabu Bekor are fried coconut paste } \\
\text { (Kerisik), shrimp paste, bird's eye } \\
\text { chilies, lemon grass, galangal, kesom } \\
\text { leave, and salt. }\end{array}$ & $\begin{array}{c}\text { Some } \\
\text { K'ledge } \\
4.25\end{array}$ & $\begin{array}{c}\text { Full } \\
\text { K'ledge } \\
5.00\end{array}$ & $\begin{array}{c}\text { Full } \\
\text { K'ledge } \\
5.00\end{array}$ & $\begin{array}{c}\text { Some } \\
\text { K'ledge } \\
4.79\end{array}$ & $\begin{array}{c}\text { Some } \\
\text { K'ledge } \\
4.61\end{array}$ \\
\hline 4 & $\begin{array}{l}\text { Caution on the choice of coconut milk to } \\
\text { be used in preparing Kerabu Bekor }\end{array}$ & $\begin{array}{c}\text { Some } \\
\text { K'ledge } \\
4.00\end{array}$ & $\begin{array}{c}\text { Full } \\
\text { K'ledge } \\
5.00\end{array}$ & $\begin{array}{c}\text { Full } \\
\text { K'ledge } \\
5.00\end{array}$ & $\begin{array}{c}\text { Some } \\
\text { K'ledge } \\
4.79\end{array}$ & $\begin{array}{c}\text { Some } \\
\text { K'ledge } \\
4.73\end{array}$ \\
\hline 5 & $\begin{array}{l}\text { Kerabu Bekor can be served as daily } \\
\text { food, for events such as feast and } \\
\text { breaking fast. }\end{array}$ & $\begin{array}{c}\text { Some } \\
\text { K'ledge } \\
4.25\end{array}$ & $\begin{array}{c}\text { Full } \\
\text { K'ledge } \\
5.00\end{array}$ & $\begin{array}{c}\text { Full } \\
\text { K'ledge } \\
\\
5.00\end{array}$ & $\begin{array}{c}\text { Some } \\
\text { K'ledge } \\
4.75\end{array}$ & $\begin{array}{c}\text { Some } \\
\text { K'ledge } \\
4.61\end{array}$ \\
\hline
\end{tabular}

\subsection{This section focused on the Kerabu Bekor as the traditional food product and the following 8 factors would be discussed:}

- Main ingredients used in the preparation Kerabu Bekor

- Methods in which Kerabu Bekor is being prepared and the reasons for preparing that way.

- Equipment used to prepare Kerabu Bekor

- Origin of Kerabu Bekor

- Occasion Kerabu Bekor will be served

- For whom Kerabu Bekor is prepared and the reasons.

- The ways Kerabu Bekor is served to the guest.

- Other foods can be served with Kerabu Bekor

\section{Factor 1: Main ingredients used in the preparation of Kerabu Bekor}

The 5 food experts indicated that the main ingredients were usually derived from plants around the house.

Main Ingredients in the Preparation of Kerabu Bekor:

Bekor fruit sliced

Lemongrass bruised and crushed

Shallots peeled, sliced, and crushed

Fried grated coconut (paste)

Galangal peeled and crushed

Vietnamese coriandersliced and crushed 
Kerabu Bekor: Exploring the Traditional Food Knowledge of the Community in the Lenggong SubDistrict of Hulu Perak

\section{Ingredient $A$}

Tamarind

Thick coconut milk

\section{Ingredient $B$}

Bird's eye chilies

Dried prawn (shrimp) paste

Seasoning

Salt

Table 5 listed the main ingredients that would be required to make Kerabu Bekor

Table 5 Main Ingredients in Kerabu Bekor

\begin{tabular}{|c|c|c|c|}
\hline & & & \\
\hline \multicolumn{4}{|r|}{$\begin{array}{l}\text { ients used for } \\
\text { some area in } \\
\text { padi), which } \\
\text { ich tend to be } \\
\text { shrimp paste } \\
\text { t smell. Once } \\
\text { flavour to the } \\
\text { of the coconut } \\
\text { round to make } \\
\text { coconut milk. } \\
\text { our. Tamarind } \\
\text { ntributes a tart }\end{array}$} \\
\hline
\end{tabular}

Factor 2. The methods Kerabu Bekor is prepared and the reasons for preparing it in that way

The food experts stated the methods of preparing and cooking the Kerabu Bekor.

\section{Method of Cooking}

- Combine water and bekor in a saucepan. Bring to boil and simmer. There are two methods, best if bekor is grilled over a fire in order to extract its real sweet taste.

- Add in lemongrass and shallot into a mortar and pestle and crushed.

- Add in remaining ingredient particularly Vietnamese coriander, ingredient A, galangal, ingredient $\mathrm{B}$, fried grated coconut and salt (to taste) in sequence and stir until it blends well.

- Lastly, add in boiled bekor and mix well.

Table 6 Showed each of the expert's opinion on the methods of preparing Kerabu Bekor 
Table 6 Methods of Preparation of Kerabu Bekor

\begin{tabular}{|l|c|c|c|c|}
\hline Expert 1 & Expert 2 & Expert 3 & Expert 4 & Expert 5 \\
\hline Overall, the second question tracked the Bekor fruits preparation have two ways given by experts \\
during the interviewed session. The bekor fruit must be roasted on the fire coal until a nice smell \\
that come out from the fruit the colour will turn into black or burn, the test will be more delicious \\
and sweet because the juice will not be oozing out but if boil the smell will less strong and taste \\
will be bitter
\end{tabular}

\section{Factor 3: Equipment used to prepare Kerabu Bekor}

The food experts indicated the equipment or utensils that would be required to prepare Kerabu Bekor.

\section{Tools/Utensils used in making the Kerabu Bekor}

On equipment and utensils used, there was no proper equipment and utensils to use as long that the ingredients could be prepared accordingly and mixed together. But some people used 'rawah' (similar to flower pot). For roasting the bekor fruit, it could be roast on the satay burner or wooden burner.

In respond to the question, the food experts believed that without wooden stove the bekor fruit could also be roasted on the gas stove, but the taste would not be the same when using wooden stove.

Table 7 showed the equipment or utensils that would be required to prepare Kerabu Bekor.

Table 7 Equipment/Tools used in Preparing Kerabu Bekor

\begin{tabular}{|c|c|c|c|c|}
\hline Expert 1 & Expert 2 & Expert 3 & Expert 4 & Expert 5 \\
\hline \multicolumn{5}{|c|}{$\begin{array}{l}\text { Overall, on equipment and utensils used, there is no proper equipment and utensils to use as long } \\
\text { that the ingredients can be prepared accordingly and mixed together. But some people use 'rawah' } \\
\text { (similar to flowerpot). For roasting the bekor fruit can be roast on the satay burner or wooden } \\
\text { burner. } \\
\text { In respond to the question, expert } 5 \text { believed that without wooden stove the bekor fruit can be roast } \\
\text { on the gas stove but the taste will not be the same when using wooden stove. }\end{array}$} \\
\hline
\end{tabular}

\section{Factor 4: Origin of Kerabu Bekor}

The 5 experts indicated the origin of Kerabu Bekor

\section{Origin of Kerabu Bekor}

In tracking the experts' understanding, most believed that the idea of making Kerabu Bekor came from their great grandparents from Pattani.

\section{Brief Historical Perspective of the Site}

The study area was the Lenggong sub-district which is in the Hulu Perak District. The Hulu Perak comprises of 10 sub-districts (called mukims) and three district councils. They were:

- Pengkalan Hulu District Council

- Pengkalan Hulu (with Klian Intan)

- Belukar Semang

- Gerik District Council

- Gerik (with Kuala Rui)

- Belum

- Kenering (with Lawin)

- Kerunai 
Kerabu Bekor: Exploring the Traditional Food Knowledge of the Community in the Lenggong SubDistrict of Hulu Perak

- Temenggor (with Banding Island)

- Lenggong District Council

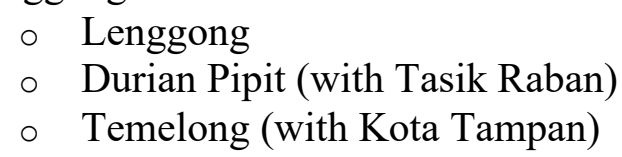

The Hulu Perak areas had a strong influence by the historical region of Patani from the Southern Thailand provinces. From the 1500s until the 19th century, a good part of this district was under the sovereignty of Siam, as part of the old Malay kingdom of Reman. The area was then under control of Thailand and included what is today the areas of Gerik, Pengkalan Hulu (Kroh), Kerunai, the Belum forest and the Temenggor Lakes. As such, traditional foods from Patani such as Kebebe, Air Lawa, Umbut Bayas, and Gulai Umbut Pisang Hutan are known as Hulu Perak traditional foods and they represented the authenticity of Perak cuisines, but they may soon become extinct if preservation efforts are not undertaken.

Table 8 indicated where the Kerabu Bekor originated from:

Table 8 Origin of Kerabu Bekor

\begin{tabular}{|c|c|c|c|c|}
\hline Expert 1 & Expert 2 & Expert 3 & Expert 4 & Expert 5 \\
\hline
\end{tabular} $\begin{aligned} & \text { Overall, in tracking the informants understanding, majorityof the experts believed that the idea of } \\
& \text { making Kerabu Bekor came from their grad grandparents from Pattani. }\end{aligned}$

Factor 5: The occasion where Kerabu Bekor would be served to the guests

The food experts indicated the occasions when Kerabu Bekor is served.

\section{Occasions when Kerabu Bekor is served}

The experts responded to the question based on their experience, Kerabu Bekor would be difficult to prepare for a big event or occasion because to prepare it, the ingredients would be difficult to get and the preparation would require a lot of steps. Thus, Kerabu Bekor would usually be prepare when there is a death, or a wedding ceremony in the community.

The experts' opinions is shown in Table 9.

Table 9 Occasion Kerabu Bekor will be Served to the Guests

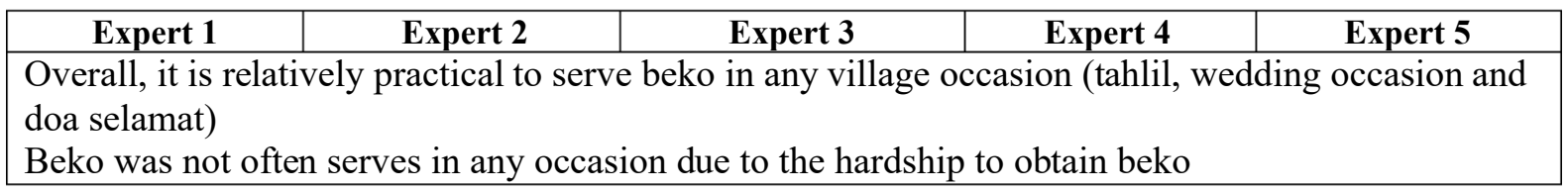

\section{Factor 6: For whom Kerabu Bekor is prepared and the reason for preparing it.}

The 5 traditional food experts indicated each of their response to this factor.

\section{Who prepare the Kerabu Bekor and for who}

From the experts' understanding there was no taboo required in the preparation of Kerabu Bekor, but it was prohibited to eat for those who hadjust given birth because it could give them internal body chill. Also, the Bekor fruit cannot be eaten raw because it taste bitter. 
Table 10 showed that Kerabu Bekor is usually prepared for:

Table 10 For whom and Reasons for Preparing Kerabu Bekor

\begin{tabular}{|c|l|}
\hline Expert 1 & $\begin{array}{l}\text { Since the process require much efforts, I normally serve for those minimal guests } \\
\text { that came to my house. }\end{array}$ \\
\hline Expert 2 & Family consumption. \\
\hline Expert 3 & It is our family daily meals, nowhere to found in any occasion here \\
\hline Expert 4 & Beko was not often serves in any occasion due to the hardship to obtain beko. \\
\hline Expert 5 & $\begin{array}{l}\text { I always serve beko for our own family consumption. However, for any occasion, it } \\
\text { certainly requires additional ingredient to enrich the flavours, particularly bean } \\
\text { sprout, ferns, and beef stomach. }\end{array}$ \\
\hline
\end{tabular}

\section{Factor 7: The ways the food is being served to the guest.}

On a consensus, the experts indicated the follow in regard to the factor.

\section{Ways in which the food is served}

It could be served in a tray for 4 persons. However, today it is common to serve Kerabu Bekor on plate.

Table 11 Indicated the way Kerabu Bekor is mainly served to the guests.

Table 11 How Kerabu Bekor is Served

\begin{tabular}{|c|c|c|c|c|}
\hline Expert 1 & Expert 2 & Expert 3 & Expert 4 & Expert 5 \\
\hline $\begin{array}{l}\text { Well, it } \\
\text { depends, but } \\
\text { I think today } \\
\text { it is } \\
\text { common to } \\
\text { serve beko } \\
\text { in plate }\end{array}$ & $\begin{array}{l}\text { I prefer to use a } \\
\text { small plate. In } \\
\text { occasion here, we } \\
\text { normally serve it } \\
\text { in a tray for } 4 \text { pax }\end{array}$ & $\begin{array}{l}\text { I always use plate } \\
\text { to serve beko }\end{array}$ & $\begin{array}{l}\text { Plate is always } \\
\text { the best option }\end{array}$ & $\begin{array}{l}\text { In the olden } \\
\text { community days, we } \\
\text { use tin plate to serve } \\
\text { beko. Today, it is } \\
\text { more practical and } \\
\text { common to use plate } \\
\text { to serve }\end{array}$ \\
\hline
\end{tabular}

\section{Factor 8: Other foods that could be served with Kerabu Bekor.}

The experts agreed on the following:

\section{Other foods can be served with Kerabu Bekor}

In respond to the question, Kerabu Bekor could be eaten together with cooked rice or glutinous rice as main dishes for special occasion. However, it is preferred to be consumed by itself.

Table 12 showed the other foods that were usually served with Kerabu Bekor.

Table 12 Other Foods that are served together with Kerabu Bekor

\begin{tabular}{|c|c|c|c|c|}
\hline Expert 1 & Expert 2 & Expert 3 & Expert 4 & Expert 5 \\
\hline $\begin{array}{l}\text { Kerabu Beko } \\
\text { can eat } \\
\text { together with } \\
\text { cooked rice" }\end{array}$ & $\begin{array}{l}\text { Kerabu Beko } \\
\text { can eat together } \\
\text { with cooked } \\
\text { rice, glutinous } \\
\text { rice or kerabu } \\
\text { Beko itself" }\end{array}$ & $\begin{array}{l}\text { "Kerabu } \\
\text { Beko can eat } \\
\text { immediately. } \\
\text { " }\end{array}$ & No Information & $\begin{array}{l}\text { Basically, Kerabu Beko } \\
\text { can eat together with } \\
\text { cooked rice or glutinous } \\
\text { rice, but normally people } \\
\text { prefer to eat Kerabu Beko } \\
\text { individually. }\end{array}$ \\
\hline
\end{tabular}


Kerabu Bekor: Exploring the Traditional Food Knowledge of the Community in the Lenggong SubDistrict of Hulu Perak

\section{SUMMARY AND CONCLUSIONS}

There were four objectives for this study, and they were to identify the traditional foods in area of study, which was the Hulu Perak District, to examine the basic ingredients of the identified traditional foods. To understand the common methods of preparation and cooking of the identified traditional foods in Hulu Perak District, and to Determine the level of foodways knowledge on the identified traditional foods amongst the youths in the Hulu Perak District.

The process of identifying the traditional foods of Hulu Perak was through a focus group process which comprised of 5 prominent individuals from the Hulu Perak district who were asked on the popular traditional food of the area. The list of traditional food was derived, and upon the consensus among the members of the focus group. One of the three traditional foods derived was Kerabu Bekor.

On analyzing the perception of the different demographic variables towards Kerabu Bekor, there was an insignificant difference on the level of knowledge between the male and female respondents for Kerabu Bekor. However, there was a significant difference on the level of knowledge among the different age categories of respondents.

The exploration and findings on the Kerabu Bekor as a traditional food in sub-district of Lenggong in Hulu Perak could add towards enriching the variety of culinary tourism products of Hulu Perak and to the state of Perak as a whole. It could be used as a reference to generate ideas, innovations and business opportunities for the rural community. Findings from the study could help to ensure that the knowledge on Kerabu Bekor as a traditional foods could be preserved once the results is published, and that the video could be distributed and be seen by those interested in the information. The study could be used as a model or framework in examining the traditional foods available in other areas of the country. It is hoped that this study could generate or provide the benchmark, basis, and impetus for future directions on studies of traditional foods and also in diversifying the culinary tourism products.

\section{REFERENCES}

[1] Bowen, R. L., \& Devine, C. M. (2011). "Watching a person who knows how to cook, you'll learn a lot". Linked lives, cultural transmission, and the food choices of Puerto Rican girls. [Research Support, Non-U.S. Gov't]. Appetite, 56(2), 290-298.

[2] Chenhall, C. (2011). Improving Cooking and Food Preparation Skills: A Synthesis of the Evidence to Inform Program and Policy Development (P.-C. P. H. Network, Trans.). Vancover Canada: Public Health Agency of Canada.

[3] European Union. (2007). European Research on Traditional Foods. Belgium: Publications.europa.eu.

[4] Hamzah, H., Ab Karim, M. S., Othman, M. \& Hamzah, A. (2013). Dimensions of Authenticity in Malay Cuisine from Experts' Perspectives. Academic Journal of Interdisciplinary Studies, 2 (3), 369-377.

[5] Jaffe, J., Gertler, M. Victual(2006) Vicissitudes: Consumer Deskilling and the (Gendered) Transformation of Food Systems. Agric Hum Values 23, 143-162 (2006).

[6] Jalis, M. H. (2009). Western Tourists Perception of Malaysian Gastronomic Products. Asian Social Science, 5 (1), 25-36.

[7] Jordana (2000) Traditional foods: challenges facing the European food industry Food Research International Volume 33, Issues 3-4, April 2000, Pages 147-152 
Munira Saaidin, Annis Jamaluddin, Erdaizzati Mohd Som, Nur Juliana Azhari,

W. Eddie Azlie W. Mohd Asri and Mislan Nenin

[8] Kristbergsson (2016) Functional Properties of Traditional Foods. Integrating Food Science and Engineering Knowledge: Into the Food Chain. Publication: Springer Science+Business Media New York. ISBN 978-1-4899-7660-4.

[9] Kwik, J. (2008). Traditional Food Knowledge: A Case Study of an Immigrant Canadian "Foodscape". Environments Journal Volume, 36(1), 59-74.

[10] Langgat, J. (2011). The Alteration of Sarawak Ethnic Natives' Food: Its Impact to Sarawak State Tourism. $2^{\text {nd }}$ International Conference on Business and Economic Research, 684-698.

[11] Lestari, S. (2014) The tradition to donate among women in Javanese rural areas:

[12] Reciprocity, food exchange and monetization. Vol.6(7), pp. 205-213, July 2014.

[13] Md. Sharif, M. S., Mohd Zahari, M. S., Ishak, N., Muhammad, R., Md. Noor, A. \& Mohd. Salleh, H. (2012). Traditional Food Knowledge (TFK) of Malaysia Festive Foods. Current Issues in Hospitality and Tourism Research and Innovation.

[14] Muhammad, R., Mohd Zahari, M. S., Mohamad Abdullah, K. \& Md. Sharif, M. S. (2014). Young Generation Practices on Malaysian Ethnic Festival Foodways. Asian Conference on Environment-Behaviour Studies, 300-307.

[15] Noriza, I, Mohd Zahari, M. S., Shazali, M. S. \& Rosmaliza, M. (2012). Acculturation, Foodways And Malaysian Food Identity. Current Issues in Hospitality and Tourism Research and Innovation.

[16] Ohiokpehai, O. (2003). Promoting the Nutritional Goodness of Traditional Food Products. Pakistan Journal of Nutrition, 2(4), 267-270.

[17] Rebecca LeHeup (2011) The Rise of Food Tourism. Ontario Culinary Tourism Alliance + Skift.

[18] Stringer, R. E. (2009). The domestic foodscape of young low-income women in Montreal: Cooking practices in the context of an increasingly processed food supply. Health Education and Behaviour, 37(2), 211-226.

[19] Suhaimi, M. Z. \& Mohd Zahari, M. S. (2014). Common Acceptable Cuisine in Multicultural Countries: Towards Building the National Food Identity. International Journal of Social, Behavioral, Educational, Economic and Management Engineering, 8 (3), 855-861.

[20] Tibere, L. \& Aloysius, M. (2013). Malaysia as a Food-Haven Destination: The Vision and its Sustainability. Asia-Pacific Journal of Innovation in Hospitality and Tourism APJIHT, 2 (1), $37-51$

[21] Wahyudi David, Charles Darwin (2014), Perception of young people toward their traditional food. Asia Pacific Journal of Sustainable Agriculture Food and Energy. Vol. 2. No. 2. ISSN: 2338 - 1345 